\title{
Wanted: A New Index to Exhibition Catalogues
}

The absence of bibliographical control over, and index entries into, the substantial body of exhibit catalogs produced annually by the world's museums works considerable hardship on art libraries and their patrons. This paper urges that steps be taken soon to fill this important lacuna in bibliographical coverage of art literature.

\section{N} OT LONG AGO, in an article dealing with "Bibliographical Organization in the Humanities," Conrad Rawski quoted from Brunetière these words of wisdom: "Qui scit ubi scientia sit, ille est proximus habenti." 1 The simple truth of this dictum will certainly not be contested by scholars or by reference librarians, but what surprises the reader of the article is that its author seems so well pleased with the general state of bibliographical services for art and that he is apparently not aware of a major missing link in the bibliographical chain spanning the field. Professor Rawski, who is a teacher and not a practicing librarian, can be forgiven for his lack of consciousness of where the shoe pinches art librarians, bibliographically speaking. Others who are closer to the firing line have felt that pinch for several years. James Humphry III, until recently Chief Librarian of the Metropolitan Museum of Art, has pointed a finger at this crucial information gap in a special issue

${ }^{1}$ Conrad H. Rawski, "Bibliographical Organization in the Humanities," Wilson Library Bulletin, XL (April 1966), 746.

Dr. Freitag is Art Librarian in the Fogg Museum at Harvard University. of Library Trends devoted to subject bibliography:

The publication of catalogs in conjunction with museum and gallery exhibitions has signalled a great need for bibliographical control of this increasingly important material. These catalogs are no longer a two or three-page handout to serve as a guide for the casual visitor, but often represent a scholarly oeuvre-catalogue of definite documentation relative to the works exhibited, and with extremely useful bibliographies. $^{2}$

In 1962 Jane Clapp published her bibliography of Museum Publications ${ }^{3}$ in which a small number of exhibition catalogues are listed. The emphasis on her work, however, is published catalogues of permanent museum collections. Only those exhibition catalogues in print and obtainable from museums at the time of compilation of the bibliography are included. Important categories of catalogues, such as the catalogues of museums listed in Books in Print, and therefore available through regular book

\footnotetext{
2 James Humphry III, "Architecture and the Fine Arts," Library Trends, XV (January 1967), 483.

'Jane Clapp, Museum Publications: Part I. Publications in Anthropology, Archaeology and Art (New York: Scarecrow Press, 1962).
} 
trade channels, are specifically excluded. The most useful feature of the book is the index, which lists in one alphabet authors and subjects. These refer the information seeker to the publication number which is assigned to each entry in the bibliography. Unfortunately, the non-serial character and the geographical and editorial limitations of Museum Publications, which also attempts to cover anthropology and archaeology in addition to art, severely limits its usefulness as a reference tool. Another bad feature is the many misspelled names and titles.

The reason so many libraries have found it necessary to compile their own systematic indexes to exhibit catalogues is that the two most important current bibliographies, Art Index and Répertoire d'Art et d'Archéologie, have not been able to cope with this large and difficult segment of art literature.

For many years the reference library of the world-famous firm of art dealers, M. Knoedler and Co., has struggled valiantly to keep au courant its index to exhibition catalogues. This index attempts to establish, without a break, the complete documentation of each individual art object shown that has ever been of professional interest to the company or has passed through its sales rooms. Every summer teams of college students have found employment, trying to catch up with the accumulated indexing back$\log$ and producing great quantities of index cards that must be filed and stored in a formidable bank of catalogue card cabinets. The race against time and the swelling flood of new catalogues makes the task of catching up a more hopeless one every year.

It is not so much the quality of the many outstanding scholarly catalogues, which serve as vehicles for the latest research results and which are also made available later in hardcover format as monographs, that are solely to blame, but rather the fantastic increase in numbers of the many not-so-scholarly catalogues which are nevertheless important for the documentation of art historical facts that so utterly defy handling by traditional bibliographical methods. In his book, The Museum Age, ${ }^{4}$ Germain Bazin makes the statement that there are today more than four thousand museums in the United States alone, and that a new one opens every three and one-third days. Since most of these museums publish catalogues occasionally and some quite regularly, and since the museum age is not limited geographically to North America, it is obvious that we have arrived at a turning point in the history of art bibliography. How long will it take before the flood of exhibition catalogues engulfs us all?

The Art Index does not cover exhibition catalogues at all, although it does include reviews of exhibitions which apper in periodicals and museum bulletins. The Répertoire d'Art et d'Archéologie, which goes beyond the scope of a periodical index and does list monographs as well as articles, includes a very limited number of exhibition catalogues, all of them of monographic calibre; they are identified by the symbol for monographs, i.e., an asterisk which precedes the item number, and the notation "-Exposition" which follows the body of the bibliographical entry. The extent to which exhibition catalogues are covered in this selective bibliography is, of course, absolutely inadequate. Moreover, the time required for the preparation and publication of the Répertoire results in a time lag of two or three years, which makes it practically useless as a reference tool for "current awareness" and current factual information.

A solution to these problems of coverage and timeliness has been attempt-

\footnotetext{
4 Germain Bazin, The Museum Age (New York: Universe Books, 1967), p. 260.
} 
ed by a specialist bookselling organization in the United States. In 1963 the Worldwide Art Catalogue Centre of New York City brought out a pilot issue of a quarterly entitled The Worldwide Art Catalogue Bulletin. ${ }^{5}$

The Bulletin indexes and abstracts the catalogues of circa five hundred museums and galleries in twenty countries in Europe and America. The abstracts are written by specialists under the direction of an able editor, Eva Kroy Wisbar. The Bulletin is an excellent first step in the right direction, that of universal bibliographical coverage of exhibition catalogues. It is doubtful that it can ever be more than the first step. At the present time WACB lists only those catalogues of which the Centre is able to procure sufficient quantities for commercial distribution, and even as the firm expands its network of agents to gather this elusive type of literature, which in many countries does not even get into the regular booktrade, it cannot hope also to expand a bibliographical by-product which must by its very nature remain a nonprofit, if not a moneylosing, proposition. And yet this beginning is excellent. These bibliographical listings should not be allowed to wither because of lack of funds; rather, they ought to be expanded in several directions at once.

Obviously, exhibition catalogues which fulfill an archival as well as a current information function and which today are of the first importance for art scholars, museum curators, dealers, and collectors will have to be gathered more quickly before they go out of print, and all parts of the world must be covered more systematically. The Worldwide Art Catalogue Centre as a booktrade organization should be free to concentrate on this end of the operation. But the cata-

\footnotetext{
${ }^{5}$ The Worldwide Art Catalogue Bulletin (New York: Worldwide Art Catalogue Centre, v. 1, Fall 1963).
}

logues must also be indexed differently from the serial and periodical articles with which the present bibliographical services deal, and for this a separate organization is needed. Both the works of art themselves, that constitute the content of exhibition catalogues, and the literature about them should be analyzed in much greater detail and in greater depth than has been possible with traditional methods of abstracting and indexing. For instance, random access should be possible to the following types of information: Artists, Media, Locations, Provenance, Iconography (Subject), Chronology of Exhibitions, Collectors, Sponsoring Organizations, Principal Bibliography for each work mentioned. All this information should be cumulated at regular intervals to form a permanent bibliographical record of the literature as well as a documentation of the works shown.

It is obvious, from the exacting demands upon the new tool which we envisage, that it can only be produced with the aid of today's most advanced data processing technology, and that it will require a considerable staff of expert abstractors. Ideally, the editorial offices of the New Index should be located at the site of a master collection of the catalogues from which the information is culled. In time, after a sufficient amount of information has been collected, the computerized index could form the basis for an art historical data bank and referral center. It would be possible to prepare specialized bibliographies on demand and to retrieve specific information from the data stored. Repackaging and selective dissemination of information on the basis of user profiles would be a major activity of the center and perhaps even one that has certain business possibilities for defraying part of the costs.

Convinced that the formidable prob- 
lems of information and document control in the fine arts demand radically new methods for their solution, a group of nine American art historians, museum curators, and art librarians met in New York early in the spring of 1967, and in May of that year submitted an application for a grant to the Council on $\mathrm{Li}$ brary Resources. The grant would have enabled the group to conduct an economic feasibility study for the project which has been described in the preceding paragraphs. Unfortunately, after an initially favorable reception, the application was later dropped by the Council, partly because of a shift in its policy and partly because of ongoing projects of a technically similar nature which it was supporting.

The need for a solution to the problem of bibliographical control of exhibition catalogues continues to exist. Today it is even more pressing than it was two years ago, and it is not likely that it will diminish in the foreseeable future. The writer of this article, who convened the New York meeting in 1967, hopes that by bringing the problem once again to the attention of educational foundations, learned societies, bibliographers, information scientists, and bibliographical publishers, it might attract the interest of some organization capable of conquering it.

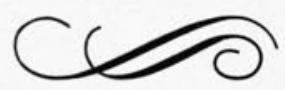

